\title{
Surgery first approach in orthodontics: An updated review
}

\author{
Akshata Gailot ${ }^{1}$, Hiral Bulsara ${ }^{2}$, Anushka Parakh ${ }^{3}$, Ramandeep Singh Sangar ${ }^{4}$ and Gabriela Fernandes ${ }^{5 *}$ \\ ${ }^{1}$ Y.M.T. Dental College and hospital, Kharghar, Navi Mumbai, India \\ ${ }^{2}$ Bhartiya Vidyapeeth dental college and hospital, Kharghar, Navi Mumbai, India \\ ${ }^{3}$ Nair Dental College and Hospital, Mumbai, India \\ ${ }^{4}$ MGM Dental College and Hospital, Kamothe, Navi Mumbai, India \\ ${ }^{5}$ Department of Oral Biology, School of dental medicine, SUNY Buffalo, Buffalo, New York, USA
}

\begin{abstract}
Skeletal malocclusion appears to be one of the most commonly encountered problems in current orthodontics. SFA- surgical first approach in orthodontics, a fresh treatment concept has recently been seen trending in order to overcome dentofacial abnormalities. The sparking evidence of the quality treatment outcomes has created an appraisal in its use. Owing to its short-therapy time and prompt esthetic modification, SFA has turned out to be ideal treatment alternative for various complicated procedures. This article will provide an overview of the surgical first orthodontic approach.
\end{abstract}

\section{Introduction}

The term "orthognathic surgery" was first coined in 1849 by Hullihen, back when surgical procedures in orthodontics were uncommon [1,2]. It wasn't until 1960, when clinicians started using the surgical approach due to its proven efficacy $[1,3]$. The increase in demand for flawless and fast esthetics has led to a rise in the use of the surgical approach. Conventional non-surgical procedures may be disadvantageous as they frequently result in caries, root resorption, gingival recession and many times the patient may be disheartened as often there is temporary worsening of facial esthetics [4-7]. The surgical line provides more bone turnover in a relatively shorter time span because of the regional acceleratory phenomenon which enables the patient to acknowledge the improved facial appearance speedily. SFA has commonly been used in Asian countries such as Japan and Korea.

\section{Surgical techniques}

- Mandibular surgery

- Maxillary surgery

- Dentoalveolar surgery

- Distract osteogenesis

- Adjunctive facial procedures: rhinoplasty, lip procedures, chin modifications

\section{Goals of orthodontic surgery}

- esthetics

- stability

- minimizing treatment time

- fixing structural deformities

- functional occlusion

- speech

\section{Indications and contraindications}

The various indications for the surgical approach prior to orthodontic correction include mild crowding, flat curve of spee, slight proclination/retroclination of incisors, minimal transverse discrepancies, patients with facial asymmetries and patients that may be having a cleft lip or palate [8-10].

Contraindications for SFA include patients that needs definite decompression, patients with severe crowding, arch incoordination and patients with severe vertical or transverse discrepancies [10].

\section{RAP: Regional acceleratory phenomenon}

It was introduced in 1983 by Frost [11] where he claimed that injury somehow accelerated the normal regional healing process and this acceleration is called regional acceleratory phenomenon. RAP is the tissue reaction to noxious stimuli that increases the healing capacity of tissues and causes increased rate of orthodontic movement, increased remodeling and transient osteopenia [12]. RAP is typically seen in hard tissues but it may be seen in soft tissues also $[13,14]$.

Regional: demineralization occurs at both cut sites as well as the adjacent bone.

Acceleratory: exaggerated or intensified bone response in cuts that extend in the bone marrow.

\section{Treatment planning consideration}

Careful treatment planning is the key to success of surgery [10].

${ }^{\star}$ Correspondence to: Gabriela Fernandes, Department of Oral Biology, School of dental medicine, SUNY Buffalo, Buffalo, New York, USA, E-mail: gfernand@buffalo.edu

Key words: surgery first, orthognathic sugery, dentofacial deformities

Received: August 30, 2018; Accepted: September 25, 2018; Published: September 27, 2018 
1. Molar relationship is taken as the starting point for temporary occlusion.

2. Inclination of incisors is important in determining the need for possible extractions, as rule of thumb, if the upper incisors are excessively proclined (angulation 53 to 55 degrees) then extraction must be done.

3. Midlines must coincide or be close to it with proper bilateral buccal overjet.

4. Final occlusion based on current position of the teeth will later help in splint fabrication and skeletal movement therefore three-point contact should be present between upper and lower models.

\section{Protocol variations}

Although the lines of treatment may be similar, different protocols are generally used to prepare patients for the treatment [15]. In most cases brackets and wires are placed right before surgery [10]. Passive stainless wires are most commonly used to prevent tooth movement but some orthodontists have opted for nickel-titanium wires [10]. Furthermore, surgical splint can also be advocated during surgery or post surgically, i.e. around one to four weeks after surgery.

\section{Advantages of SFA}

- immediate change in facial profile

- chief complaint of the patient is addressed since the beginning of treatment

- faster results

- future orthodontic treatment becomes less complicated

- easier to deal with relapses as compared to routine orthodontic treatment because decompensation is completed before surgery

\section{Disadvantages of SFA}

- planning may be time consuming as it needs to be very accurate to prevent any errors

- predicting final occlusion is difficult

- ideal occlusion may be hard to achieve if there are multiple dental interferences

- patient selection is of utmost importance

\section{Post-surgical complications}

- TMD

- Paraesthesia

- Decreased bite force

- Relapse

- Risk to patient due to complexity of osteotomy procedures

\section{Conclusion}

SFA serves to be the present-day treatment archetype for dentofacial deformity management [16]. With its direct and rapid bony modification, it has proven to show satisfactory results and elevated acceptance $[16,17]$. The vital factor in achieving successful outcomes are the experienced surgeons and orthodontists that take into account the patients' well-being and needs [18]. The patients' needs and goals should always be of first priority as even the slightest error can be very difficult to correct.

\section{References}

1. Goldwyn RM (1973) Simon P. Hullihen: pioneer oral and plastic surgeon. Plast Reconstr Surg 52: 250-257. [Crossref ]

2. Laskin DM (1973) Simon P. Hullihen: surgeon, teacher, humanitarian. J Oral Surg 31: 503. [Crossref]

3. Church LE (1988) Simon P. Hullihen, pioneer and expert in oral surgery. Bull Hist Dent 36: 39-43. [Crossref]

4. Haider SM, Latif W (2018) Oral \& Maxillofacial Surgery; A historical review of the development of the surgical discipline. Int J Surg 55: 224-226. [Crossref ]

5. Gonzalez Navarro B, Jane Salas E, Estrugo Devesa A, Lopez Lopez J, Vinas M (2017) Bacteremia associated with oral surgery: A Review. J Evid Based Dent Pract 17: 190204. [Crossref]

6. Corkery PF (1969) Bone and tooth cutting in oral surgery. A review of methods in current use. J Ir Dent Assoc 15: 27-30. [Crossref ]

7. Ikejiri S (1967) Review of oral surgery. Nihon Shika Ishikai Zasshi 20: 555-561. [Crossref]

8. Wei H, Liu Z, Zang J, Wang X (2018) Surgery-first/early-orthognathic approach may yield poorer postoperative stability than conventional orthodontics-first approach: a systematic review and meta-analysis. Oral Surg Oral Med Oral Pathol Oral Radiol 126: 107-116. [Crossref ]

9. Yu CC, Chen PH, Liou EJ, Huang CS, Chen YR (2010) A Surgery-first approach in surgical-orthodontic treatment of mandibular prognathism--a case report. Chang Gung medical journal 33: 699-705. [Crossref ]

10. Huang CS, Chen YR (2015) Orthodontic principles and guidelines for the surgery-firs approach to orthognathic surgery. Int J Oral Maxillofac Surg 44: 1457-1462. [Crossref ]

11. Frost HM (1983) The regional acceleratory phenomenon: a review. Henry Ford Hospital medical journal 31: 3-9.

12. Verna C (2016) Regional acceleratory phenomenon. Front Oral Biol 18: 28-35 [Crossref]

13. Singer LD (2013) Periodontally accelerated orthodontics: ER,Cr:YSGG laser-induced regional acceleratory phenomenon. Dentistry today 32: 94, 96-97.

14. Teng GY, Liou EJ (2014) Interdental osteotomies induce regional acceleratory phenomenon and accelerate orthodontic tooth movement. J Oral Maxillofac Surg 72 19-29. [Crossref ]

15. Choi JW, Bradley JP (2017) Surgery first orthognathic approach without presurgica orthodontic treatment: questions and answers. J Craniofac Surg 28: 1330-1333. [Crossref ]

16. Liou EJ, Chen PH, Wang YC, Yu CC, Huang CS, et al. (2011) Surgery-first accelerated orthognathic surgery: postoperative rapid orthodontic tooth movement. J Oral Maxillofac Surg 69: 781-785. [Crossref ]

17. Liou EJ, Chen PH, Wang YC, Yu CC, Huang CS, et al. (2011) Surgery-first accelerated orthognathic surgery: orthodontic guidelines and setup for model surgery. J Oral Maxillofac Surg 69: 771-780. [Crossref]

18. Uribe F, Agarwal S, Shafer D, Nanda R (2015) Increasing orthodontic and orthognathic surgery treatment efficiency with a modified surgery-first approach. Am J Orthod Dentofacial Orthop 148: 838-848. [Crossref]

Copyright: (C)2018 Gailot A. This is an open-access article distributed under the terms of the Creative Commons Attribution License, which permits unrestricted use, distribution, and reproduction in any medium, provided the original author and source are credited. 